\title{
Anthropometric characteristics and cardiorespiratory capacity of male and female trail runners
}

\author{
July Melo', Oscar Niño², Gabriel Montoya², Yovany Castro², Miguel Garzón², Norma Quiroga², Daniel Castillo³, Javier Yanci \\ 'Facultad de Educación y Deporte. Universidad del País Vasco. UPV/EHU. Vitoria-Gasteiz. España. ${ }^{2}$ Facultad de Ciencias del Deportey la Educación Física. Universidad de Cundina- \\ marca. Fusagasugá. Colombia. ${ }^{3}$ Facultad de Ciencias de la Salud. Universidad Isabell. Burgos. España. ${ }^{4}$ Society, Sports and Physical Exercise Research Group (GIKAFIT). Departamento \\ de Educación Física y Deportiva, Facultad de Educación y Deporte, Universidad del País Vasco, UPV/EHU, Vitoria-Gasteiz, España.
}

doi: $10.18176 /$ archmeddeporte.0005

Received: $14 / 10 / 2019$ Accepted: 02/07/2020

Key words: Trail running. Morphology. Body composition.

Cardiovascular capacity. Endurance. High performance.

\section{Summary}

Introduction: The objectives of this study were to compare the anthropometric characteristics and the cardiorespiratory capacity of male and female mountain runners, and to examine the association between anthropometric and cardiorespiratory variables.

Material and method: A total of 48 mountain runners, 16 women and 32 men take part in the study. Anthropometric parameters were measured and a maximum incremental test was performed on treadmill with ramp for cardiorespiratory assessment. Results: The results showed significant differences in the anthropometric characteristics corresponding to mass, height, body mass index (BMI), perimeters, diameters, \% muscle mass, \% residual mass and mesomorphic component between men and women, being significantly higher in the male group $(p<0.05)$. The female group obtained significantly higher values $(p<$ 0.05) in tricipital, thigh, leg and ilecorestal skinfolds, as well as in 8 folds sum, \% fat, fat mass, bone mass and in the endomorphic component. With respect to cardiorespiratory capacity, the male group obtained significantly higher values in the initial systolic volume $(p<0.01, T E=-1.45$, large), oxygen consumption at the second ventilatory threshold $(\mathrm{VO}, \mathrm{VT} 2)(p<0.01, \mathrm{TE}$ $=-1.66$, large) and maximum oxygen consumption $\left(\mathrm{VO}_{2} \max \right)(\mathrm{p}<0.05, \mathrm{TE}=-1.78$, large). A large correlation was obtained between the sum of 8 skinfolds and the $\mathrm{VO}_{2} \max (r=-0.79, \mathrm{p}<0.01)$, between the $\%$ fat and the $\mathrm{VO}_{2} \max (r=-0.81, p<0.01)$ and between $\%$ fat and $\mathrm{VO}_{2} \mathrm{VT} 2(r=-0.79, \mathrm{p}<0.01)$.

Conclusions: The results seem to show differences between male and female mountain runners in anthropometric characteristics and cardiorespiratory capacity and that anthropometric characteristics can influence the cardiorespiratory performance of mountain runners.

\section{Características antropométricas y capacidad cardiorrespiratoria de corredores de montaña masculinos y femeninos}

\section{Resumen}

Introducción: Los objetivos de este estudio fueron comparar las características antropométricas y cardiorrespiratorias de corredores de montaña masculinos y femeninos, y examinar la asociación entre las variables antropométricas y cardiorrespiratorias. Material y métodos: Un total de 48 corredores de montaña, 16 mujeres y 32 hombres participaron en el estudio. Se midieron los parámetros antropométricos y se realizó un test incremental máximo en tapiz rodante con rampa para la valoración cardiorrespiratoria.

Resultados: Los resultados arrojaron diferencias significativas en las características antropométricas correspondientes a masa, talla, índice de masa corporal (IMC), perímetros, diámetros, \% masa muscular, \% masa residual y componente mesomórfico entre hombres y mujeres, siendo significativamente superiores en el grupo masculino $(p<0,05)$. El grupo femenino obtuvo en pliegues tricipital, muslo, pierna e ilecorestal, así como en la suma $\Sigma 8$ pliegues, \% de grasa, en la masa grasa, masa ósea y en el componente endomórfico valores significativamente mayores $(p<0,05)$. Con respecto a la capacidad cardiorrespiratoria, el grupo masculino obtuvo valores significativamente mayores en el volumen sistólico inicial ( $p<0,01, T E=-1,45$, alto), consumo de oxígeno en el segundo umbral ventilatorio $\left(\mathrm{VO}_{2} \mathrm{VT} 2\right)(\mathrm{p}<0,01, \mathrm{TE}=-1,66$, alto $)$ y consumo de oxígeno máximo

Palabras clave:

Carreras de montaña. Morfología. Composición corporal. Capacidad cardiovascular. Resistencia. Alto rendimiento. $\left(V_{2}{ }_{\text {máx }}\right)\left(p<0,05, T E=-1,78\right.$, alto). Se obtuvo una correlación alta entre la suma de 8 pliegues y el $V_{2 \text { máx }}(r=-0,79, p<0,01)$, entre el $\%$ de grasa y el $\mathrm{VO}_{2 \text { máx }}(r=-0,81, p<0,01)$ y entre el $\%$ de grasa y el $\mathrm{VO}_{2} \mathrm{VT} 2(r=-0,79, p<0,01)$

Conclusiones: Los resultados parecen evidenciar diferencias entre corredores de montaña hombres y mujeres en las características antropométricas y en la capacidad cardiorrespiratoria y que las características antropométricas pueden influir en el rendimiento cardiorrespiratorio de los corredores de montaña. 


\section{Introduction}

Trail running is a speciality that takes place in a natural setting ${ }^{1}$, regulated by the International Trail Running Association (ITRA). Participants compete on irregular terrain, subject to different climatology and at variable altitudes oscillating between $0 \mathrm{~m}$ and over 4,000m. Despite trail runs today covering different distances, the most common are competitions ranging from $42 \mathrm{~km}$ to over $100 \mathrm{~km}$, lasting a single day or with stages spanning over various days ${ }^{2}$. Due to the characteristics of competition, athletes specialising in this modality are subject to high physical and physiological demands and require low fat percentages, a suitable percentage of muscle mass, major joint stability, and correct metabolic efficiency that enables them to maintain good running economy to ensure optimum performance ${ }^{3,4}$. Despite the major increase in popularity of trail races, to date there are few scientific studies that analyse these specific variables among this sporting demographic ${ }^{5}$.

Due to the high physical demands of competition, anthropometry has been described as a relevant factor in sporting performance for this modality ${ }^{6}$. Specifically, in trail runners, a study carried out by RamírezVélez et al. ${ }^{5}$ analysed the body composition and somatotype of elite category runners, observing that participants had $13.3 \pm 3.2 \%$ body fat, a sum of the six folds of $67.8 \pm 32.0 \mathrm{~mm}$ and an endomorphic (3.6 \pm 1.5 ), mesomorphic (4.0 \pm 1.4 ) and ectomorphic (2.1 \pm 1.1$)$ somatotype. Another recent study ${ }^{7}$ analysed the differences in the anthropometric characteristics of trail runners of different sex, concluding that there were differences in the anthropometric characteristics of men and women (body mass index: $71.9 \pm 5.6$ vs. $59.9 \pm 4.8$ kg.m ${ }^{-2}$, body fat percentage: $12.4 \pm 3.0$ vs. $20.0 \pm 4.9 \%$, total lean mass: $60.9 \pm 5.7$ vs. $46.2 \pm 2.6 \%$, total lean mass of legs: $20.1 \pm 1.9$ vs. $15.5 \pm 2.0$ ). Despite there being anthropometric studies on trail runners in different contexts, as well as before and after competition $^{8}$, there are few studies that analyse the differences between male and female trail runners, as there have been in other resistance modalities ${ }^{9-11}$. Therefore, studies should be carried out that characterise and identify whether there are differences in the anthropometric characteristics and in the somatotype of trail runners depending on sex.

On the other hand, descriptions have claimed that as well as requiring a suitable body composition, cardiorespiratory capacity is another crucial factor in trail running performance ${ }^{6}$. This assessment is of interest to athletes and coaches in order to plan customised training sessions and as a sporting performance predictor ${ }^{12}$. For example, Hausswirth et al. (2015), analysed the cardiorespiratory capacity [maximum oxygen consumption $\left(\mathrm{VO}_{2} \mathrm{max}\right.$ ), the maximum aerobic velocity and ventilatory thresholds (VT1 and VT2)] of trail runners. Along the same line, recent studies have also analysed oxygen consumption $\left(\mathrm{VO}_{2}\right)$, ventilatory thresholds (VT1 and VT2), lactate thresholds, running economy, mechanical and maximum power ${ }^{14}$ or maximum heart rate (maxHR), the $\left(\mathrm{VO}_{2} \mathrm{max}\right)$, ventilatory threshold $(\mathrm{VT})$, the lactate concentration in the blood and rate of perceived exertion (RPE) ${ }^{15}$. Specifically, these authors ${ }^{13}$ observed how the participating trail runners had a $\mathrm{VO}_{2}$ max of $62.0 \pm 63.9$ $\mathrm{ml} \cdot \mathrm{min}^{-1} . \mathrm{kg}^{-1}$, maximum aerobic velocity (MAV) of $18.7 \pm 1.1 \mathrm{~km} \cdot \mathrm{h}^{-1}$, a
VT1 at $14.2 \pm 60.7 \mathrm{~km} \cdot \mathrm{h}^{-1}$ and a VT2 at $16.7 \pm 61.2 \mathrm{~km} \cdot \mathrm{h}^{-1}$. Despite there being studies that assess trail runners' cardiorespiratory capacity ${ }^{14,15}$ there are few examples of studies that analyse differences by sex. More studies may be required to analyse whether there are differences in the cardiorespiratory capacity of female and male trail runners.

Therefore, the aims of this study were: 1) to compare the anthropometric and cardiorespiratory characteristics of male and female trail runners, and 2) to examine the link between anthropometric characteristics and cardiorespiratory capacity.

\section{Material and method}

\section{Participants}

Forty-eight top level Colombian trail runners (30.81 \pm 2.56 years; $165.2 \pm 7.5 \mathrm{~cm} ; 61.04 \pm 8.47 \mathrm{~kg} ; 22.29 \pm 2.50 \mathrm{~kg} . \mathrm{m}^{-2}$ ) participated in this study. Of the total number of participants, 16 were female $(29.5 \pm 7.6$ years; $\left.158.9 \pm 6.2 \mathrm{~cm} ; 53.37 \pm 3.64 \mathrm{~kg} ; 20.89 \pm 1.53 \mathrm{~kg} \cdot \mathrm{m}^{-2}\right)$ and 32 were male (32.0 \pm 12.7 years; $\left.168.1 \pm 6.2 \mathrm{~cm} ; 64.87 \pm 7.53 \mathrm{~kg} ; 22.99 \pm 2.61 \mathrm{~kg} . \mathrm{m}^{2}\right)$. All the participants competed frequently at national (Colombia) and international level, and actively trained between 4 to 6 days a week, with 1 or 2 days of rest or recovery. The training sessions held comprised 1 or 2 days of recovery running, 1 day of extensive running, 1 day of intensive running, 1 day of sets, 1 day of intervals, with participants performing 1 or 2 days of strength training. The relationship with the amount of training hours carried out by the athletes varied between 10 and 20 hours a week, reaching totals of between 5,000 and 10,000 m of accumulated gradient each week. The inclusion criteria for participation in this study were for the trail runners to be following structured and consecutive training, to have participated in official competitions during the previous quarter to the tests, and to have no injury, metabolic or inflammatory disease of any kind that may risk the athletes' health. Before performing the research, each of the athletes were informed about the protocols and the study test that would be carried out, and they all signed an informed consent form. The study was reviewed and approved by the Sports Science and Physical Education Faculty of the University of Cundinamarca (Fusagasugá, Colombia), which adhered to the ethical guidelines stipulated in the Helsinki Declaration (2013).

\section{Procedure}

The tests and measurements were performed in the University of Cundinamarca physiology department (Fusagasugá, Colombia), located approximately 1,700 m above sea level. In a single session, the participants attended the laboratory where their anthropometric measurements were taken, then a maximal incremental test was carried out on a treadmill. The laboratory conditions were between $21-23^{\circ} \mathrm{C}$ in temperature and with 70-75\% relative humidity. All participants indicated that they had refrained from performing intense exercise or taking caffeinated or alcoholic drinks in the 48 hours prior to the test session. 


\section{Measurements}

Anthropometric assessment, body composition and somatotype: All the measurements were performed in adherence with the rules standardised by the International Society for the Advancement of Kinanthropometry (ISAK) ${ }^{16}$. Measurements were taken of the subscapularis, tricipital, abdominal, suprailiac, thigh, leg, bicipital and iliac crest folds with skin fold callipers (Harpenden, West Sussex, United Kingdom). Next, the participants' height was measured with a height rod (Seca 217, Hamburg, Germany), and body mass with a mechanical weighing scale (Detecto Scale, Missouri, USA). The perimeters of the neutral thorax, abdomen, hips, extended arm, bent arm, thigh and leg of each participant were measured with an anthropometric tape (Mabis Healthcare 35-780-010, Alabama, USA). The biachromial, transverse thorax, bi-ileocrestal and elbow measurements were taken with an anthropometer (GPM Siber Hegner Maschinery type Martin, Zurich, Switzerland). Finally, to establish the body composition and somatotype, the Spanish Group of Kineanthropometry (GREC, Spanish acronym), from which the percentage of muscle mass, bone mass and remaining were established, as well as mesomorphy, ectomorphy and endomorphy ${ }^{17}$.

A maximum incremental test was performed on a treadmill with a ramp: all participants performed a maximum incremental test, adhering to the findings made by Davis et al. ${ }^{18}$ to determine cardiorespiratory capacity. The test started with a warm-up at a constant speed of 3 $\mathrm{km} \cdot \mathrm{h}^{-1}$ for 3 minutes. Next, the speed was increased to $9 \mathrm{~km} \cdot \mathrm{h}^{-1}$, the test commencing with an initial gradient of $0^{\circ}$. The slope progressively increased by $2^{\circ}$ every minute, to eventually reach $15^{\circ}$. From this point, the speed was increased by $1 \mathrm{~km} . \mathrm{h}^{-1}$ a minute, to reach volemia extenuation. Before starting the test, the resting heart rate (RHR) of each athlete was recorded using a band (Polar $\mathrm{H}_{3^{\prime}}$ Kempele, Finland) and a heart rate monitor (Polar $\mathrm{RCX}_{3^{\prime}}$ Kempele, Finland). Both before and after finishing the test, blood pressure (systolic and diastolic) was taken using an automatic blood pressure metre (Omrom M6, Kyoto, Japan), and the blood oxygen saturation $\left(\mathrm{SpO}_{2}\right)$ was measured with a finger pulse oximeter (Deluxe SM-110, Tustin, USA). Throughout the entire test, the heart rate (HR) of each athlete was recorded constantly using a band (Polar $\mathrm{H}_{3^{\prime}}$ Kempele, Finland) and a heart rate monitor (Polar $\mathrm{RCX}_{3}$, Kempele, Finland). Furthermore, during the test the athletes wore a portable system for measuring ventilatory parameters (Cortex Biophysik, MetaMax 3B portable CPX System, Leipzig, Germany) with an oronasal silicone mask (Hans Rudolph, Shawnee, USA). Data was analysed using specific software (Cortex Biophysik MetaSoft ${ }^{\circledR}$ Studio (MSS) CPX, Leipzig, Germany). To establish the ventilatory threshold 1 (VT1) and 2 (VT2), the method proposed by López-Chicarro J, et al. ${ }^{19}$ was used. At the end of the test, all the athletes stated their reported perception of exertion (final RPE) using the Abellán Alemán ${ }^{20}$ scale of 6-20.

\section{Statistical analysis}

The results are displayed as average \pm typical deviation (TD). The data normality test was performed using the Shapiro-Wilk test, and the homogeneity of variance (homoscedasticity) was measured using the Levene test. The variables followed a normal distribution, therefore parametric tests were performed. The differences between the male and female groups in anthropometric characteristics, body composition, somatotype and in cardiorespiratory capacity, were established using a t-test for independent samples. The difference of averages was also calculated (Dif. $\%)$ as well as the size of effect (SE) ${ }^{21}$ to discover the differences between the groups for practical purposes. SE below (0.2), between (0.2 and 0.5), between (0.5 and 0.8), greater than (0.8) were considered trivial, low, moderate and high, respectively ${ }^{21}$. The associations between variables were calculated using the Pearson correlation coefficient ( $r$ ). To interpret the correlation magnitudes, the following scale was used: lower than (0.1) trivial; from (0.1 to 0.3) low; from (0.3 to 0.5) moderate; from (0.5 to 0.7) high; (0.7 to 0.9) very high; more than (0.9) almost perfect. The data was analysed using the Statistical Package for Social Science (SPSS ${ }^{\oplus}$ Inc, version 23.0 for Windows, Chicago, IL, USA). The significance level was established at $p<0.05$. In cases in which despite the differences not being significant, the sizes of effect were high (SE $>0.8$ ), these were considered differences for practical purposes.

\section{Results}

The results corresponding to the anthropometric characteristics, the body composition and the somatotype of the trail runners that participated in this study, as well as the comparison by sex, are displayed in Table 1, Figure 1 and Figure 2. The results obtained in this study reveal significant differences between the male and female groups, with values corresponding to mass, height, BMI, perimeters, diameters, muscle mass percentage, remaining percentage and mesomorphic component being higher in the male group ( $p<0.01$ or $p<0.05$ ). However, the group of female runners obtained significantly higher values $(p<0.01$ or $p<0.05$ ) in the tricipital, thigh, leg and ileocrestal folds, as well as in the sum of folds, in fat percentage, in fat mass, bone mass and in the endomorphic component. No significant differences were observed in terms of subscapularis, abdominal, suprailiac and ileocrestal folds, in the perimeter of the hips and thighs, and in the ectomorphic component.

Table 2 displays the results of the maximum incremental test obtained in the laboratory for the trail runners. The male group obtained significantly higher values in the initial systolic value $(p<0.01, \mathrm{SE}=$ -1.45 , high), in the $\mathrm{VO}_{2} \mathrm{VT} 2\left(p<0.01, \mathrm{SE}=-1.66\right.$ high) and in the $\mathrm{VO}_{2}$ max $(p<0.05, \mathrm{SE}=-1.78 \mathrm{low})$. However, the female group of runners obtained significantly higher values than the male group in $\mathrm{SaPO}_{2} \mathrm{Max}$. exercise ( $p<0.01$, SE $=1.16$, high).

With regards to the association between the age of the runners and anthropometric characteristics, a low correlation was observed ( $r=0.37$ to $0.49, p<0.01)$ between age and weight, abdominal fold, $\mathrm{BMI}$, neutral thorax perimeter, bent arm perimeter, transverse thorax diameter, bone mass percentage, remaining percentage and weight index, and a moderate correlation ( $r=0.51$ to $-0.65, p<0.01$ ) between age and the abdominal perimeter, extended arm perimeter and the peak HR in the maximum incremental test.

Finally, regarding the link between the anthropometric or body composition characteristics and the incremental test results in the 
Table 1. Results of the anthropometric characteristics, body composition and somatotype of all participants and differences depending on the sex of mountain runners.

\begin{tabular}{|c|c|c|c|c|c|c|}
\hline Variable & All & Males & Females & Dif. (\%) & SE & $P$ \\
\hline \multicolumn{7}{|l|}{ General } \\
\hline Mass $(\mathrm{Kg})$ & $61.04 \pm 8.47$ & $64.87 \pm 7.53$ & $53.37 \pm 3.64$ & -17.72 & -2.06 & ** \\
\hline Height $(\mathrm{cm})$ & $165.02 \pm 7.49$ & $168.06 \pm 6.15$ & $158.94 \pm 6.18$ & -5.43 & -1.48 & ** \\
\hline $\mathrm{BMI}\left(\mathrm{kg} \cdot \mathrm{m}^{-2}\right)$ & $22.29 \pm 2.50$ & $22.99 \pm 2.61$ & $20.89 \pm 1.53$ & -9.11 & -1.01 & * \\
\hline \multicolumn{7}{|l|}{ Folds } \\
\hline Subscapularis (mm) & $13.21 \pm 5.16$ & $12.85 \pm 5.20$ & $13.98 \pm 5.18$ & 8.34 & 0.21 & \\
\hline Tricipital (mm) & $9.53 \pm 3.04$ & $7.86 \pm 1.61$ & $12.86 \pm 2.42$ & 63.58 & 2.48 & ** \\
\hline Abdominal (mm) & $17.43 \pm 6.67$ & $16.66 \pm 7.10$ & $18.97 \pm 5.61$ & 13.88 & 0.36 & \\
\hline Suprailiac $(\mathrm{mm})$ & $10.72 \pm 5.24$ & $9.78 \pm 5.70$ & $12.59 \pm 3.64$ & 28.80 & 0.60 & \\
\hline Thigh $(\mathrm{mm})$ & $11.98 \pm 6.01$ & $9.10 \pm 3.03$ & $17.74 \pm 6.40$ & 94.98 & 1.83 & ** \\
\hline $\operatorname{Leg}(\mathrm{mm})$ & $8.04 \pm 4.67$ & $5.90 \pm 1.96$ & $12.32 \pm 5.57$ & 108.68 & 1.70 & ** \\
\hline Bicipital (mm) & $4.64 \pm 2.43$ & $3.59 \pm 1.31$ & $6.73 \pm 2.80$ & 87.47 & 1.53 & ** \\
\hline Iliocrestal (mm) & $11.65 \pm 5.92$ & $10.77 \pm 6.48$ & $13.39 \pm 4.27$ & 24.34 & 0.49 & \\
\hline$\Sigma 8$ Folds $(\mathrm{mm})$ & $87.19 \pm 29.88$ & $76.51 \pm 26.37$ & $108.53 \pm 24.14$ & 41.85 & 1.24 & ** \\
\hline \multicolumn{7}{|l|}{ Perimeters } \\
\hline Neutral thorax $(\mathrm{cm})$ & $92.13 \pm 7.27$ & $95.38 \pm 5.79$ & $85.64 \pm 5.37$ & -10.21 & -1.75 & ** \\
\hline Abdomen $2(\mathrm{~cm})$ & $79.15 \pm 6.92$ & $81.32 \pm 6.44$ & $74.80 \pm 5.84$ & -8.02 & -1.06 & ** \\
\hline Hips (cm) & $92.71 \pm 3.97$ & $92.74 \pm 4.41$ & $92.66 \pm 3.03$ & -0.09 & -0.02 & \\
\hline Extended arm (cm) & $28.15 \pm 2.37$ & $28.85 \pm 2.27$ & $26.73 \pm 1.94$ & -7.35 & -1.01 & * \\
\hline Bent arm $(\mathrm{cm})$ & $29.26 \pm 2.80$ & $30.51 \pm 2.42$ & $26.78 \pm 1.61$ & -12.21 & -1.85 & ** \\
\hline Forearm $(\mathrm{cm})$ & $24.50 \pm 1.95$ & $25.51 \pm 1.38$ & $22.49 \pm 1.22$ & -11.82 & -2.31 & ** \\
\hline Thigh $(\mathrm{cm})$ & $55.15 \pm 7.00$ & $55.66 \pm 8.00$ & $54.13 \pm 2.51$ & -2.75 & -0.28 & \\
\hline $\operatorname{Leg}(\mathrm{cm})$ & $34.50 \pm 2.26$ & $35.06 \pm 2.33$ & $33.48 \pm 1.75$ & -4.50 & -0.77 & * \\
\hline \multicolumn{7}{|l|}{ Diameters } \\
\hline Biachromial $(\mathrm{cm})$ & $37.22 \pm 2.72$ & $38.23 \pm 2.63$ & $35.22 \pm 1.57$ & -7.86 & -1.43 & $* *$ \\
\hline Transverse thorax $(\mathrm{cm})$ & $27.43 \pm 2.25$ & $28.43 \pm 1.93$ & $25.43 \pm 1.34$ & -10.56 & -1.84 & ** \\
\hline Bi-iliocrestal $(\mathrm{cm})$ & $27.99 \pm 2.91$ & $27.90 \pm 1.36$ & $28.16 \pm 4.75$ & 0.92 & 0.08 & \\
\hline Elbow $(\mathrm{cm})$ & $6.38 \pm 0.54$ & $6.62 \pm 0.40$ & $5.89 \pm 0.46$ & -11.04 & -1.70 & ** \\
\hline \multicolumn{7}{|l|}{ Body composition } \\
\hline Waist and hips index & $22.29 \pm 2.50$ & $0.54 \pm 0.20$ & $0.78 \pm 0.34$ & 44.69 & 0.89 & * \\
\hline Fat mass $\%$ & $14.36 \pm 5.13$ & $12.45 \pm 4.75$ & $18.18 \pm 3.52$ & 46.02 & 1.38 & ** \\
\hline Bone mass \% & $26.57 \pm 5.31$ & $24.87 \pm 5.34$ & $29.97 \pm 3.29$ & 20.49 & 1.18 & ** \\
\hline Muscle mass \% & $42.92 \pm 4.05$ & $44.41 \pm 3.57$ & $39.93 \pm 3.31$ & -10.08 & -1.30 & ** \\
\hline Rest \% & $16.86 \pm 6.95$ & $19.64 \pm 6.46$ & $11.29 \pm 3.95$ & -42.51 & -1.60 & ** \\
\hline \multicolumn{7}{|l|}{ Somatotype } \\
\hline Endo & $4.28 \pm 5.40$ & $3.17 \pm 1.14$ & $6.50 \pm 8.99$ & 105.49 & 0.66 & * \\
\hline Meso & $4.28 \pm 5.40$ & $4.81 \pm 1.29$ & $4.07 \pm 0.80$ & -15.35 & -0.71 & * \\
\hline Ecto & $4.56 \pm 1.19$ & $2.19 \pm 1.14$ & $2.33 \pm 0.92$ & 6.06 & 0.13 & \\
\hline Weight index & $42.02 \pm 1.60$ & $41.91 \pm 1.75$ & $42.23 \pm 1.27$ & 0.77 & 0.21 & \\
\hline
\end{tabular}

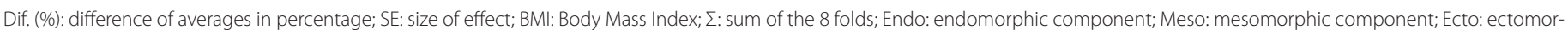
phic component. ${ }^{* *}(p<0.01) *(p<0.05)$ significant difference between the male and female group.

laboratory, a moderate correlation was observed between most of the skin folds or the body composition variables with the results obtained in the incremental test. A high correlation between the $\Sigma$ folds and the $\mathrm{VO}_{2}$ max was obtained $(r=-0.79, \mathrm{p}<0.01)$ (Figure $3 \mathrm{~A}$ ), between the fat $\%$ and the $\mathrm{VO}_{2} \max (r=-0.81, p<0.01)$ (Figure 3B) and between the fat $\%$ and the VO,VT2 $(r=-0.79, p<0.01)$ (Figure $3 C$ ).

\section{Discussion}

The aims of this study were to compare the anthropometric and cardiorespiratory characteristics of male and female trail runners, and to examine the link between anthropometric characteristics and cardiorespiratory capacity. Despite there being studies that analyse the anthropometric characteristics and cardiorespiratory performance of trail runners ${ }^{5,7,12,14}$, few studies analyse the differences between male and female trail runners. Despite differences in sex being well established in terms of physical, physiological and metabolic factors in the different sporting modalities, study protocols are heterogeneous and continue to be far from conclusive among highly-trained or elite athletes, as the differences between male and female athletes are fewer the higher the level of performance compared to amateur athletes ${ }^{23}$.

Knowing the anthropometric characteristics of resistance runners could be relevant as an important link has been described with competi- 
Table 2. Results of the maximum incremental test in the laboratory obtained from the total of all participants and differentiated by the sex of the trail runners.

\begin{tabular}{|c|c|c|c|c|c|c|}
\hline Variable & All & Males & Females & Dif. (\%) & SE & $\boldsymbol{P}$ \\
\hline \multicolumn{7}{|l|}{ Resting values } \\
\hline Resting HR (beats min $^{-1}$ ) & $64.50 \pm 11.55$ & $63.63 \pm 11.52$ & $66.25 \pm 11.78$ & 4.12 & 0.22 & \\
\hline Reserve HR (beats $\mathrm{min}^{-1}$ ) & $118.67 \pm 13.96$ & $122.03 \pm 14.57$ & $111.94 \pm 9.96$ & -8.27 & -0.82 & \\
\hline Initial systole $(\mathrm{mmHg})$ & $123.15 \pm 14.39$ & $128.88 \pm 12.17$ & $111.69 \pm 11.53$ & -13.34 & -1.45 & ** \\
\hline Initial diastole (mmHg) & $76.56 \pm 9.31$ & $77.38 \pm 10.10$ & $74.94 \pm 7.52$ & -3.15 & -0.27 & \\
\hline Resting $\mathrm{SaPO}_{2}(\mathrm{mmHg})$ & $96.88 \pm 1.41$ & $96.72 \pm 1.51$ & $97.19 \pm 1.17$ & 0.48 & 0.35 & \\
\hline Resting $\mathrm{VO}_{2}\left(\mathrm{ml}^{\prime} \mathrm{kg}^{-1} \cdot \mathrm{min}^{-1}\right)$ & $8.23 \pm 4.57$ & $7.28 \pm 1.42$ & $10.13 \pm 3.46$ & 39.05 & 0.64 & \\
\hline \multicolumn{7}{|l|}{ VT1 values } \\
\hline $\mathrm{VO}_{2} \mathrm{VT} 1\left(\mathrm{ml} \cdot \mathrm{kg}^{-1} \cdot \mathrm{min}^{-1}\right)$ & $42.33 \pm 7.80$ & $44.19 \pm 8.34$ & $38.63 \pm 5.00$ & -12.58 & -0.83 & \\
\hline VT1\% Peak VO $\left(\mathrm{ml} \cdot \mathrm{kg}^{-1} \cdot \mathrm{min}^{-1}\right)$ & $74.59 \pm 12.09$ & $72.06 \pm 11.27$ & $79.66 \pm 12.45$ & 10.55 & 0.64 & \\
\hline \multicolumn{7}{|l|}{ VT2 values } \\
\hline $\mathrm{VO}_{2} \mathrm{VT} 2\left(\mathrm{ml} \cdot \mathrm{kg}^{-1} \cdot \mathrm{min}^{-1}\right)$ & $52.33 \pm 8.50$ & $55.94 \pm 7.50$ & $45.13 \pm 5.51$ & -19.32 & $-1.66^{*}$ & \\
\hline VT $2 \%$ Peak VO $\left(\mathrm{ml}_{2} \cdot \mathrm{kg}^{-1} \cdot \mathrm{min}^{-1}\right)$ & $91.43 \pm 5.63$ & $91.04 \pm 5.38$ & $92.22 \pm 6.21$ & 1.28 & 0.20 & \\
\hline \multicolumn{7}{|l|}{ Peak values } \\
\hline Peak HR (beats $\mathrm{min}^{-1}$ ) & $182.60 \pm 11.19$ & $185.66 \pm 10.92$ & $176.50 \pm 9.30$ & -4.93 & -0.90 & \\
\hline Peak systolic value $(\mathrm{mmHg})$ & $149.60 \pm 25.16$ & $156.81 \pm 24.96$ & $135.19 \pm 19.04$ & -13.79 & -0.98 & \\
\hline Peak diastolic value $(\mathrm{mmHg})$ & $82.85 \pm 9.34$ & $84.03 \pm 8.60$ & $80.50 \pm 10.57$ & -4.20 & -0.36 & \\
\hline VO $\max \left(\mathrm{ml} \cdot \mathrm{kg}^{-1} \cdot \mathrm{min}^{-1}\right)$ & $64.24 \pm 10.90$ & $66.56 \pm 8.81$ & $51.62 \pm 7.92$ & -22.45 & $-1.78^{* *}$ & \\
\hline Peak SaPO $(\mathrm{mmHg})$ & $91.52 \pm 3.87$ & $90.31 \pm 3.96$ & $93.94 \pm 2.16$ & 4.01 & 1.16 & * \\
\hline Final RPE & $15.69 \pm 2.43$ & $16.13 \pm 1.72$ & $14.81 \pm 3.35$ & -8.13 & -0.51 & \\
\hline
\end{tabular}

\% Dif: percentage of difference; $\mathrm{SE}$ : size of effect; $\mathrm{SaPO}_{2}$ : Saturation of oxygen in the blood, HR: Heart rate; $\mathrm{VO}_{2}$ : oxygen volume; VT1:Ventilatory threshold 1; VT2: Ventilatory threshold 2, RPE: reported perception of exertion.

$* *(p<0.01) *(p<0.05)$ significant difference between the male and female group

Figure 1. Somato-chart females.

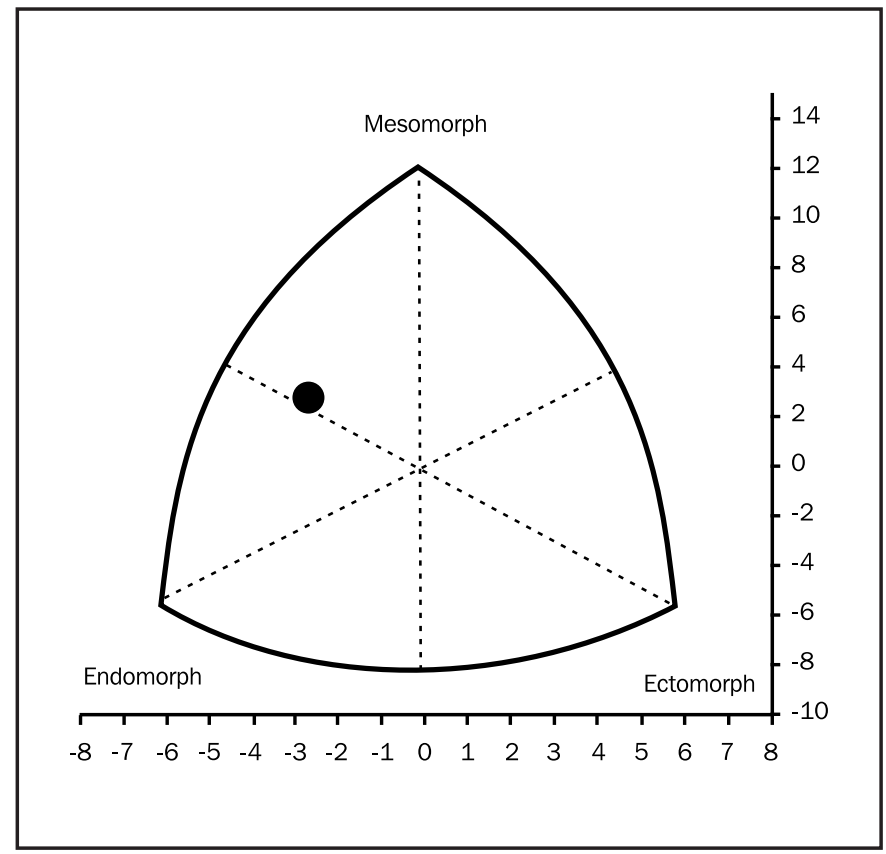

tion performance ${ }^{24}$. Previous studies have revealed that anthropometric characteristics tend to be different in male and female athletes, due principally to sexual dimorphism ${ }^{25}$. However, it is not known whether these anthropometric characteristic differences by sex also occur in
Figure 2. Somato-chart males.

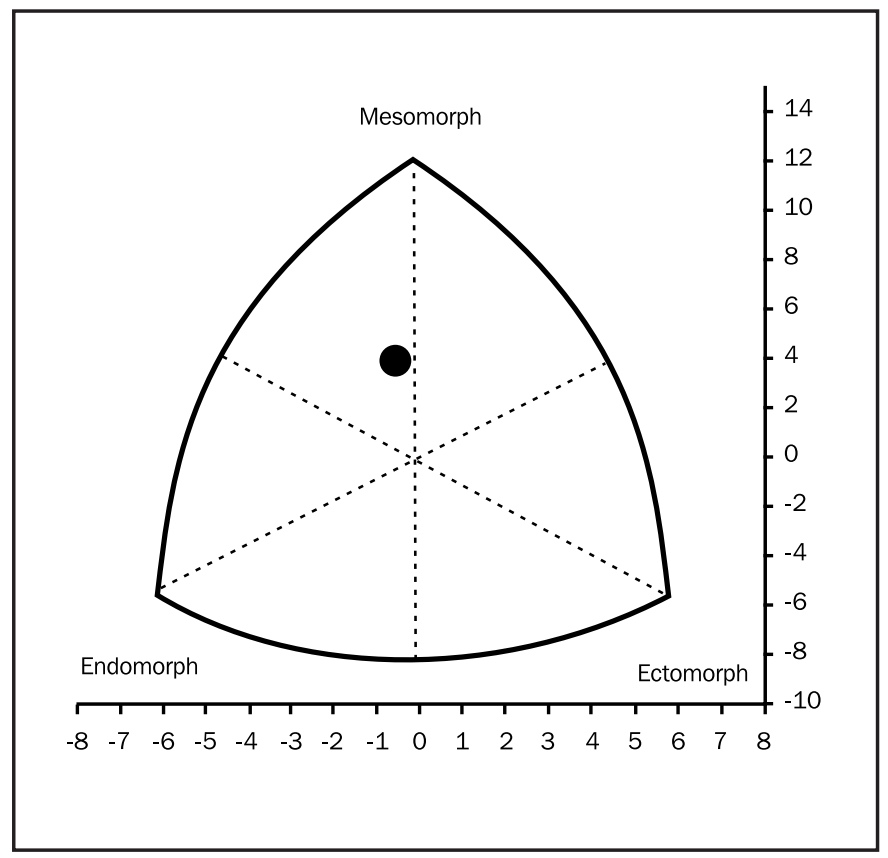

highly trained trail runners. A study performed on half marathon road runners claims that the females studied had higher skin fold values, a higher body fat percentage and lower muscle mass compared to the males ${ }^{9}$. Along the same lines, another study observes that among 
Figure 3. Results of the correlation between the sum of folds and the $\mathrm{VO}_{2} \max (3 \mathrm{~A})$, the fat percentage and the $\mathrm{VO}_{2} \max (3 \mathrm{~B})$ and between the fat percentage and the $\mathrm{VO}_{2} \mathrm{VT} 2(3 \mathrm{C})$. In trail runners. $\mathrm{VO}_{2}$ max maximum oxygen consumption; $\mathrm{VO}_{2} \mathrm{VT2}$ : oxygen consumption in the ventilatory threshold 2.

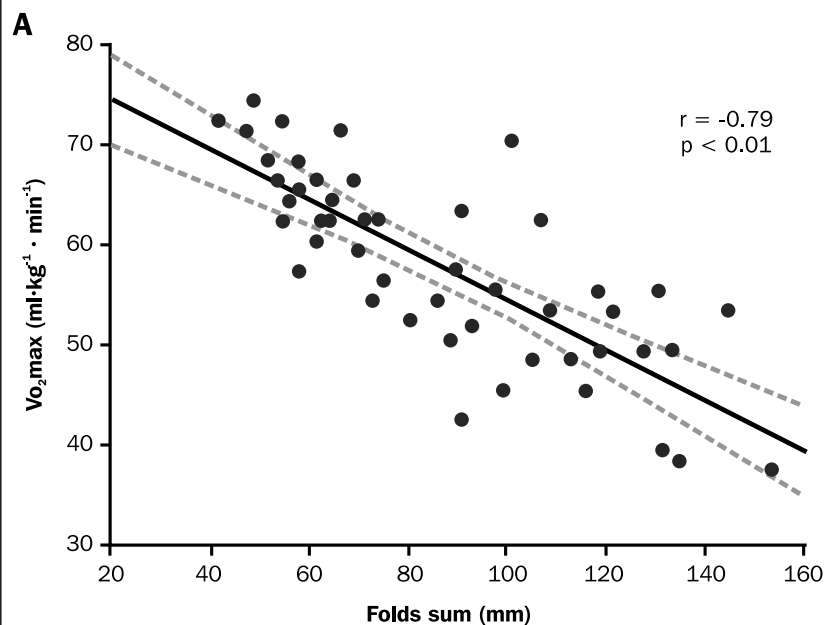

B

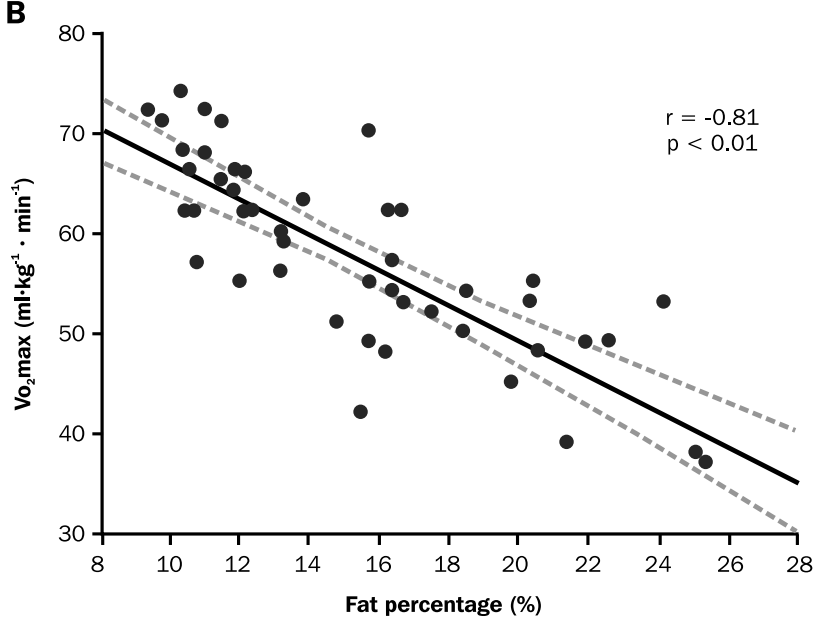

C

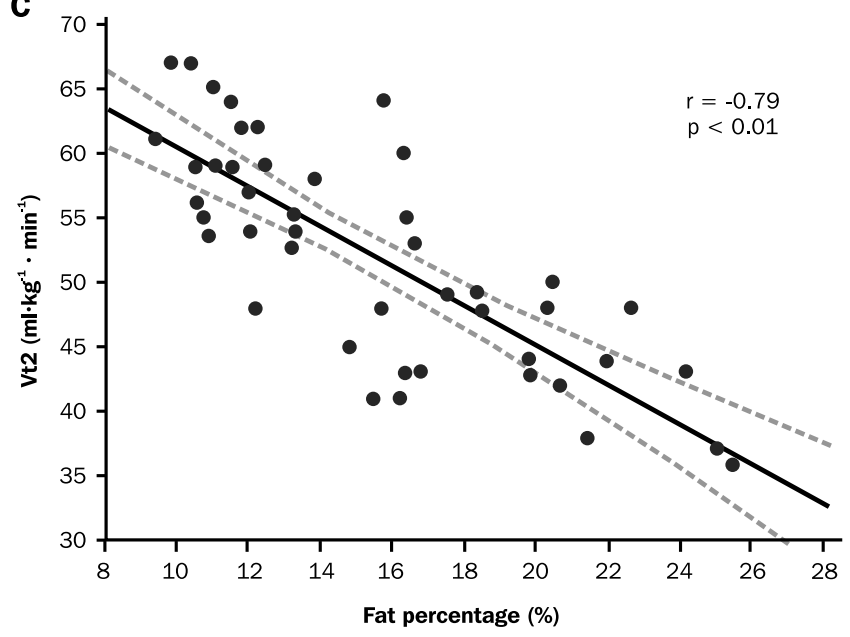

IronMan triathletes, there are significant differences between the fat percentage of male and female triathletes ${ }^{11}$. In a study performed on regional and national competing cyclists, it was observed that leg volume was significantly lower for female cyclists compared to male cyclists, a parameter linked to raw efficiency ${ }^{10}$. Most of the studies published in the literature that analyse the anthropometric characteristic differences by sex in other sporting modalities, coincide with the results obtained in our study - performed upon highly-trained trail runners - as in this study it has been observed that the females had a greater sum of the 8 skin folds and a higher fat mass than the males, whilst the group of male trail runners had a higher BMI and more muscle mass. It would appear that - as in other sporting modalities - sex can also condition the anthropometric characteristics of trail runners and can be a factor to consider due to the link this has with performance in resistance running ${ }^{26}$. It has been described how the anthropometric characteristics of runners depends significantly upon the nature of the competition, the energy requirements needed, the competition level, and the training and dietary habits of the athletes ${ }^{27,28}$. Considering that equally male and female runners must overcome major uneven ground in competition and in training, they may require suitable anthropometric characteristics that can enhance their performance?

In terms of cardiorespiratory capacity in other resistance sporting modalities, previous studies have been performed upon the difference between males and females ${ }^{25-27}$. For example, a previous study performed on mountaineer skiers observed that the males reached higher final speeds (17\%) than the females in an incremental test, as well as higher $\mathrm{VO}_{2}$ max values (7-14\%) ${ }^{30}$. Along the same lines, another study performed upon top-level competition cyclists, observed that male cyclists had a significantly higher $\mathrm{VO}_{2}$ max than the females, though these results varied depending on their level of training ${ }^{10}$. On the other hand, another study performed upon trained swimmers, who carried out a discontinuous incremental test, revealed higher $\mathrm{VO}_{2}$ max values in males, though the females displayed higher oxygen consumption linked to the first ventilatory threshold $\left(\mathrm{VO}_{2} \mathrm{VT} 1\right)$ and in the $\mathrm{HR}^{32}$. Most of the study results published coincide with those obtained in this study, in which the males displayed higher values than the females in reserve $H R$, in the initial systolic value, in the $\mathrm{VO}_{2} V T 2$, in the peak $H R$ and in the $\mathrm{VO}_{2}$ max. It appears that, just as in other resistance modality sports, cardiorespiratory capacity can be the determining factor in expressing the difference between highly trained male and female trail runners. These differences can be due to aspects such as body composition, biological potential, haemoglobin levels $(\mathrm{Hb})$ and red blood cells, or the systolic volume factor (assiduously lower among females) ${ }^{33}$, including other factors. However, considering that cardiorespiratory capacity can be improved with training ${ }^{34}$, it could be particularly relevant for trail running training sessions to focus on improving this capacity.

Scientific literature includes a host of studies in different resistance sport modalities, analysing the link between anthropometric characteristics and cardiorespiratory parameters or sporting performance ${ }^{31,32}$. For 
example, a study performed on triathletes participating in the IronMan trial, reveals that BMI is linked to the total trial time and with the time achieved in the running sector ${ }^{37}$. Along the same lines, specifically among trail runners, a study of participants in the Western States Endurance Run, covering 161 km, reveals a significant correlation between $\mathrm{BMI}$ and race speed ${ }^{38}$. The results obtained in previous studies are consistent with the results from this study, in which a high and negative correlation was found between the $\Sigma$ folds and the $\mathrm{VO}_{2} \max (r=-0.79$, $p<0.01)$, between fat $\%$ and the $\mathrm{VO}_{2} \max (r=-0.81, p<0.01)$ and between the fat $\%$ and the $\mathrm{VO}_{2} \mathrm{VT} 2(r=-0.79, p<0.01)$ among trail runners. Despite this study observing that a higher $\Sigma$ folds or higher fat $\%$ had a detrimental effect on performance in an incremental laboratory test, it did not analyse the link between anthropometric characteristics and competition performance. Some studies have revealed that the anthropometric characteristics and body composition of athletes depend on the state of training, the distance covered in the trials, and the type of modality ${ }^{39}$, therefore it would be interesting to analyse the influence that anthropometric characteristics could have on the competition performance of trail runners. However, in accordance with the results obtained in this study, the conclusion can be drawn that a lower fat \% and a lower sum of folds, can be linked to improved cardiorespiratory capacity. Therefore, one of the training targets of trail runners could be geared towards reducing their fat \% and the sum of folds.

This study is not exempt from limitations. The main constraint lies in the limited number of participants, and a lower number of female athletes. Future studies should perform assessments with a higher number of trail runners. On the other hand, this study analysed cardiorespiratory capacity in a laboratory test, thereby for later studies a field test could be suggested, a competition trial, or protocols that simulate competition. Finally, the incremental test was performed at approximately 1,726 m above sea level. This aspect may have considerably conditioned the results obtained by the runners.

\section{Conclusions}

The results obtained in this study highlight the existing differences between male and female trail runners in terms of anthropometric characteristics and cardiorespiratory capacity. The sum of skin folds and the fat percentage were higher among the females. In terms of the $\mathrm{VO}_{2}$ max the group of male runners obtained higher values than the group of females in reserve $\mathrm{HR}$, in initial systolic volume, in the $\mathrm{VO}_{2} \mathrm{VT}_{2}$, in peak $\mathrm{HR}$ and in the $\mathrm{VO}_{2}$ max. On the other hand, the results obtained in this study display a significant and high inverse correlation between the fat percentage and the $\mathrm{VO}_{2}$ max and the fat percentage and the $\mathrm{VO}_{2} \mathrm{VT} 2$, highlighting how anthropometric characteristics may influence the cardiorespiratory performance of trail runners.

\section{Conflict of interests}

The authors claim to have no conflict of interest whatsoever.

\section{Bibliography}

1. Baena Extremera A, Rebollo Rico S. Análisis del perfil sociodemográfico y competitivo del practicante de raids de aventura de ámbito nacional. Apunt Educ Física y Deport. 2009;98:68-77.

2. Goig RL, Vilanova A. Spain: a Sociological analysis of the evolution and characteristics of running. In: Running Across Europe. Palgrave Macmillan, London; 2015. p. 1-21.

3. Barnes KR, Kilding AE. Running economy: measurement, norms, and determining factors. Sport Med - Open. 2015;8(1):1-15.

4. Sainz-Fernández L, Rabadán-Ruíz M. Valoración de la condición aeróbica del corredor de orientatión a pie de alto nivel español. Arch Med Deporte. 2013;30(158):359-64.

5. Ramírez-Vélez R, Argothy-Bucheli R, Sánchez-Puccini MB, Meneses-Echávez JF, LópezAlbán CA. Características antropométricas y funcionales de corredores colombianos de élite de larga distancia. latreia. 2015;28(3):240-7.

6. Knechtle B, Duff B, Welzel U, Götz K. Body mass and circumference of upper arm are associated with race performance in ultraendurance runners in a multistage race-The Isarrun 2006. Res Q Exerc Sport. 2008;80(2):262-8.

7. Björklund G, Swarén M, Born DP, StöggIT. Biomechanical adaptations and performance indicators in short trail running. Front Physiol. 2019;10:1-10.

8. Giovanelli N, Biasutti L, Salvadego D, Alemayehu HK, Grassi B, Lazzer S. Changes in skeletal muscle oxidative capacity after a trail-running race. Int J Sports Physiol Perform. 2020;15(2):278-84

9. Friedrich M, Rüst CA, Rosemann T, Knechtle P, Barandun U, Lepers R, et al. A comparison of anthropometric and training characteristics between female and male halfmarathoners and the relationship to race time. Asian J Sports Med. 2014;5(1):10-20.

10. Hopker J, Jobson S, Carter H, Passfield L. Cycling efficiency in trained male and female competitive cyclists. J Sport Sci Med. 2010;9(2):332-7.

11. Knechtle B, Knechtle P, Barandun U, Rosemann T. Anthropometric and training variables related to half-marathon running performance in recreational female runners. Phys Sportsmed. 2011;39(2):158-66.

12. Scheer $\mathrm{V}$, Janssen $\mathrm{TI}$, Vieluf $\mathrm{S}$, Heitkamp H-C. Predicting trail running performance with laboratory exercise tests and field based results. J Int I Sport Physiol Perform. 2018;14(1):1-13.

13. Hausswirth C, Louis J, Bieuzen F, Pournot H, Fournier J, Filliard JR, et al. Effects of whole-body cryotherapy vs. far-infrared vs. passive modalities on recovery from exercise-induced muscle damage in highly-trained runners. PLoS One. 2015;6(12):1-7.

14. Scheer V, Ramme K, Reinsberger C, Heitkamp H-C. VO2 máx testing in trail runners: Is there a specific exercise test protocol? Int J Sports Med. 2018;39(06):456-61.

15. Balducci P, Clémençon M, Morel B, Quiniou G, Saboul D, Hautier CA. Comparison of level and graded treadmill tests to evaluate endurance mountain runners. J Sport Sci Med. 2016;15:239-46.

16. Marfell-Jones M, Stewart A, Olds T. International society for advancement of kinanthropometry. 1st ed. London, England: Engineering \& Technology, Sports and Leisure; 2006. $1-168 \mathrm{p}$.

17. Mazza JC. Antropometrica (Spanish version of Anthropometrica). Norton K, Olds T, editors. Rosario, Argentina: Biosistem Servicio Educativo; 1995. 1-274 p.

18. Davis JA, Whipp NL, Huntsman DJ, Frank MH, Wasserman K. Effect of ramp slope on determination of aerobic parameters from the ramp exercise. Med Sci Sports Exerc. 1982;14(5):339-43

19. López-Chicarro J, Vicente-Campos D, Cancino-Lopez J. Capitulo 3. Transición aeróbicaanaeróbica: concepto, metodología de determinación y aplicaciones. In: Editorial Médica Panamericana, editor. Fisiología del Entrenamiento Aeróbico. 2004. p. 39-45.

20. Abellán Alemán J, Sainz De Baranda Andujar P, Ortín Ortín EJ. Guía para la prescripción de ejercicio físico en pacientes con riesgo cardiovascular. 2nd ed. Murcia, España; 2014. $237 \mathrm{p}$.

21. Cohen J. Statistical power analysis for the behavioral sciences. 2nd ed. Lawrence Earlbaum Associates P, editor. New York, United States; 1988. 216 p.

22. Amorin S, Costa R, Vardasca R, Pontinga M. Resting metabolic rate, somatotype and body composition of Trail Running. Int J Sports Physiol Perform. 2016;11:1-6.

23. Ruby BC, Robergs RA. Gender differences in substrate utilisation during exercise. Sport Med. 1994;17(6):393-410.

24. Knechtle B, Knechtle P, Roseman T, Senn O. Sex differences in association of race performance, skin-fold thicknesses, and training variables for recreational Half-Marathon Runners. Percept Mot Skills. 2011;111(3):653-68.

25. Canda AS. Variables antropométricas de la población deportista española. Consejo Superior de Deportes. Madrid, España; 2012. 121 p. 
26. Knechtle B, Wirth A, Baumann B, Knechtle P, Rosemann T, Seen O. Differential correlations between anthropometry, training volume, and performance in male and female ironman triathletes. J Strength Cond Res. 2010;24(10):2785-93.

27. Clemente-Suárez VJ. Psychophysiological response and energy balance during a 14-h ultraendurance mountain running event. Appl Physiol Nutr Metab. 2015:40(3):269-73.

28. Belinchón-de Miguel P, Tornero-Aguilera JF, Dalamitros AA, Nikolaidis PT, Rosemann T, Knechtle B, et al. Multidisciplinary analysis of differences between finisher and nonfinisher ultra-endurance mountain athletes. Front Physiol. 2019;10: 1507

29. Maldonado-Martín S, Mujika I, Padilla S. Physiological variables to use in the gender comparison in highly trained runners. J Sports Med Phys Fitness. 2004;44(1):8-14.

30. Sandbakk $\varnothing$, Ettema G, Leirdal S, Holmberg HC, Lacour JR. Gender differences in the physiological responses and kinematic behaviour of elite sprint cross-country skiers. Eur J Appl Physiol. 2012;112(3):1087-94.

31. Schumacher YO, Mueller P, Keul J. Development of peak performance in track cycling J Sports Med Phys Fitness. 2001;41(2):139-46.

32. Reis JF, Millet GP, Bruno PM, VleckV, Alves FB. Sex and exercise intensity do not influence oxygen uptake kinetics in submaximal swimming. Front Physiol. 2017;8(72):1-8.
33. Gallo Flórez R. Cambios fisiológicos en la mujer deportista. Universidad de Antioquía editor. Educ Física y Deport. 1995;17(1):103-9.

34. Hoffman MD. Ultramarathon trail running comparison of performance-matched men and women. Med Sci Sports Exerc. 2008;40(9):1681-6.

35. Belli T, Meireles CLDS, Costa M de O, Ackermann MA, Gobatto CA. Somatotype, body composition and performance in ultramarathon. Rev Bras Cineantropometria e Desempenho Hum. 2016;18(2):127-35.

36. Cureton K, Bishop P, Hutchinson P, Newland H, Vickery S, Zwiren L. Sex difference in maximal oxygen uptake - Effect of equating haemoglobin concentration. Eur J App Physiol Occup Physiol. 1986;54(6):656-60

37. Knechtle B. Relationship of anthropometric and training characteristics with race performance in endurance and ultra-endurance athletes. Asian J Sports Med. 2014;5(2):73-90.

38. Hoffman MD. Anthropometric characteristics of ultramarathoners. Int J Sports Med. 2008;29(10):808-11.

39. Larry-Kenney W, Wilmore JH, Costill DL. Physiology of sport and exercise. 5th ed. Champaign, United States: Human Kinetics; 2012. 1-642 p. 